\title{
INDONESIAN LEARNERS' SELF-DIRECTED LEARNING AND RESILIENCE IN ONLINE ENGLISH CLASSES: ASSESSING INTERACTION WITH L2 ACHIEVEMENT
}

\author{
Adaninggar Septi Subekti \\ Universitas Kristen Duta Wacana (UKDW), Indonesia \\ (adaninggar@staff.ukdw.ac.id)
}

Received: $14^{\text {th }}$ May 2021; Revised: $28^{\text {th }}$ May 2021; Accepted: $29^{\text {th }}$ June 2021

\begin{abstract}
The present study was conducted to find the relationship between English for Academic Purposes (EAP) learners' Self-directed Learning (SDL) and their achievement as measured with their EAP class grades as well as the relationship between these grades and their resilience. This study used a survey as the method of data collection and 157 learners who were enrolled in EAP online classes willingly participated in the study. Results of Pearson's correlation and Regression analysis showed that learners' SDL was very weakly associated with their grades $(r(155)=.01, p>$ $.05)$, with their SDL being unable to predict their ultimate achievement $\left(R^{2}=.000\right)$. This study further found a very weak negative relationship between learners' resilience and their grades $(r$ $(155)=-.02, p>.05)$. Learners' resilience was not a predictor for their grades either $\left(R^{2}=.000\right)$. As the present study is an exploratory study of the issue in question in the Indonesian context of English as a foreign language (EFL), it is suggested that further studies be conducted to establish more conclusive findings on the predictive power of learners' SDL and resilience towards their English learning achievement.
\end{abstract}

Key Words: Self-directed Learning (SDL); resilience; L2 achievement; online learning

\section{ABSTRAK}

Studi ini bertujuan menginvestigasi hubungan antara Self-directed Learning (SDL) pembelajar kelas Bahasa Inggris untuk tujuan akademik (EAP) dan pencapaian belajar di kelas Bahasa Inggris serta hubungan antara pencapaian belajar tersebut dengan ketahanan (resilience) mereka. Studi ini menggunakan metode survei dan sebanyak 157 pembelajar di kelas EAP bermoda daring berpartisipasi dalam studi ini. Studi ini menemukan bahwa SDL pembelajar berkorelasi sangat lemah dengan pencapaian belajar $(r(155)=.01, p>.05)$ dan bahwa SDL tidak mampu memprediksi pencapaian belajar $\left(R^{2}=.000\right)$. Studi ini juga menemukan bahwa ketahanan pembelajar berkorelasi sangat lemah dengan pencapaian belajar $(r(155)=-.02, p>.05)$ dan tidak mampu memprediksi pencapaian belajar $\left(R^{2}=.000\right)$. Karena studi ini termasuk studi awal dalam kajian SDL dan ketahanan pembelajar dalam kaitannya dengan pencapaian belajar pada konteks pembelajaran Bahasa Inggris sebagai bahasa asing di Indonesia, terkait dengan hasil studi ini, disarankan dilakukan studi-studi lain dalam konteks Indonesia. Studi-studi ini dapat dilakukan untuk mendapatkan kesimpulan yang lebih solid terkait besar kecilnya kemampuan SDL dan ketahanan pembelajar dalam memprediksi pencapaian belajar mereka dalam Bahasa Inggris.

Kata Kunci: Self-directed Learning (SDL); ketahanan; pencapaian belajar bahasa Inggris; pembelajaran daring

How to Cite: Subekti, A. S. (2021). Indonesian Learners' Self-directed Learning and Resilience in Online English Classes: Assessing Interaction with L2 Achievement. IJEE (Indonesian Journal of English Education), 8(1), 1-16. doi:10.15408/ijee.v8i1.20681 


\section{INTRODUCTION}

The Covid-19 pandemic has changed the way millions of students worldwide learn, from studying on-site to online (Subekti, 2020). Due to the online mode of instruction, learners were compelled to assume more responsibility for learning in the online instructional process as the effectiveness of online learning largely depends on learners' active learning $(\mathrm{Fu}, 2013)$. For this reason, learners' Self-directed Learning (SDL) during online instruction could be paramount. SDL refers to learners' ability to make decisions, with or without teachers' prompts, and to self-direct themselves related to their learning (Basereh \& Pishkar, 2016; Sze-yeng \& Hussain, 2010). Ayyildiz and Tarhan (2015) asserted that learners with a high level of SDL can determine their goals of learning, strategies to achieve them as well as monitor and assess their achievements.

Several research studies on SDL in online learning have been conducted in various educational contexts (e.g.: Basereh \& Pishkar, 2016; Ko, 2018; Park, Sung, \& Joo, 2018; Rashid \& Asghar, 2016; Subekti, 2021; Sumuer, 2018; Uz \& Uzun, 2018) and these studies imply many researchers' acknowledgement towards the importance of SDL in learning. An experimental study by $\mathrm{Uz}$ and Uzun (2018), for instance, found that learners' SDL in the class with blended learning was significantly higher than those in the face-to-face class, suggesting that online mode of instruction was associated with a higher SDL. In a similar vein, a qualitative study in the Indonesian university context by Zainuddin, Habiburrahim, Muluk, and Keumala (2019) also found that learners' SDL was affected by interesting instructional contents. Another study by Sumuer (2018) in Turkey found that welldesigned online learning was a supporting factor for the development of learners' SDL where learners could take initiatives for their learning success.

Furthermore, in the online learning setting, SDL is considered playing a very important role in affecting learning success (Zhu, Bonk, \& Doo, 2020). In an online setting where spatial and temporal freedom possibly make learners feel disconnected and disengaged from learning (Plaisance, 2018), learners should self-direct themselves in the learning process including studying independently and asking questions to solve learning difficulties (Zhu et al., 2020).

Several studies have been conducted in the Asian context to specifically investigate the extent to 
which learners' SDL could predict their achievement in English (e.g.: Cho \& Ma, 2015; Hadi, Kalantari, \& Ghaslani, 2014; Kim, 2014; Li \& Park, 2019; Xuan Razali, \& Samad, 2018). A study in Iran by Hadi et al. (2014), for example, found that there was no significant association between learners' SDL and their achievement in English. In a similar vein, a study in the Malaysian context by Xuan et al. (2018) also found that there was no significant difference in SDL among learners from different academic achievements. In contrast, a study by Kim (2014), involving Korean High School learners, found a statistically significant association between learners' SDL and English performance. In line with Kim (2014), in a study involving 146 Korean university learners, Cho and Ma (2015) also found a positive relationship between their SDL and English proficiency. A more recent study in Korea by $\mathrm{Li}$ and Park (2019) also reported that learners' SDL could account for $10 \%$ of the variance in their English proficiency. In addition, in the Iranian university context, it was found through an experimental study that upper intermediate L2 learners' SDL affected their speaking accuracy (Majedi \& Pishkar, 2016). Regarding all these findings, though there seem to be more studies suggesting the positive effect of learners' SDL towards their L2 achievement, the findings in this particular area of SDL have thus far been inconsistent, implying conducting further studies in the field are worthwhile.

Furthermore, the online mode of instruction during the Covid-19 pandemic has been characterised by many challenges (Lancker \& Parolin, 2020; Onyema et al., 2020; Rapanta, Botturi, Goodyear, \& Guardea, 2020) and this could also test learners' level of resilience. Kim and Kim (2016) defined learners' resilience as "the sum of an individual's abilities that allow him or her to bounce back from adversity and even thrive in the face of difficult times" (p. 2). Further," Simons, Beaumont, and Holland (2018) explained that there are two core ideas in defining resilience: adversity and positive adaptations. Hence, resilient learners are those who can positively adapt when they are facing adversities (Simons et al., 2018), difficulties of learning online amidst the Covid-19 pandemic being one of them.

As reported by several recent studies in Indonesia (e.g.: Eko, Atmojo \& Nugroho, 2020; Gunawan, Suranti, \& Fathoroni, 2020), Indonesian learners still experienced some challenges in participating in online learning such as a lack of necessary resources like supporting gadgets and internet 
connection, and unfamiliarity with the online mode. In relation with these challenges, learners' resilience, their capability to bounce back in the face of adversity (Kim \& Kim, 2016), possibly plays a critical role in influencing learning success.

Though not as popular as SDL, resilience has also been investigated by various L2 research studies, mostly in the Asian context (e.g.: Danesh \& Shahnaazari, 2020; Kim, Kim, \& Kim, 2018; Kim \& Kim, 2020, 2016; Malekan \& Hajimohammadi, 2017; Nguyen, Stanley, Stanley, \& Wang, 2015; Subekti, 2021). In Korea, Kim and Kim (2016), involving 1620 secondary school learners, found that learners' resilience, seen from their persistence, could strongly predict their English as L2 proficiency and motivated learning behaviours. Kim et al. (2018) in the same Korean context also found that their elementary school learner participants reported a quite high optimism level and their resilience positively affected their L2 motivation. In the Iranian context, Kamali and Fahim (2011) reported that their participants' resilience significantly affected these participants' ability in comprehending texts containing unfamiliar vocabulary. In a similar vein, another study in Iran by Malekan and Hajimohammadi (2017) also found that learners' resilience could predict these learners' translation ability. Furthermore, several other studies in Iran also found that learners' resilience significantly predicted their L2 achievement (e.g.: Abolmaali \& Mahmudi, 2013; Khajavy, Makiabadi, \& Navokhi, 2019; Najafzadeh, Jahedizadeh, \& Ghanizadeh, 2019). A study involving 384 Iranian female High School learners by Abolmaali and Mahmudi (2013) found that these learners' resilience significantly predicted their academic achievement. In a similar vein, Najafzadeh et al. (2019) also found a statistically significant, though weak, correlation between their 173 university learner participants' resilience and their achievement in English. Another recent study in Iran also found that learners' psychological capital, their resilience being one of them, was a positive significant predictor of their achievement (Khajavy et al., 2019). The relatively same findings of these aforementioned studies could suggest that learners' resilience could be a predictor of various L2 achievements. This may be attributed to problemsolving skills resilient learners possess that allow them to have strategies to cope with learning challenges (Danesh \& Shahnaazari, 2020; Hagger \& Hamilton, 2018).

Moreover, as far as online learning is concerned, both learners' SDL and 
resilience are influenced by online learning design. For example, in Indonesia, Zainuddin et al. (2019) found in their qualitative study that welldesigned online learning increased university learners' SDL. Sumuer (2018) specifically mentioned that online learning providing the right amount of challenge, allowing collaborations, and a certain degree of flexibility could potentially nurture the growth of learners' SDL and resilience.

Overwhelming tasks should be avoided in such a setting as this could be anxiety-provoking rather than stimulating learners to develop resilience and autonomy (Rapanta et al., 2020).

In the Indonesian context, L2 learners' SDL and resilience could play a critical role in affecting their success in online L2 learning setting especially amidst the Covid-19 pandemic with all the possible challenges related to possible lack of resources and infrastructure, as well as learners' unfamiliarity with online learning. A study which paralleled this present study investigated the relationship between learners' SDL and resilience (Subekti, 2021) and it found that learners' resilience could moderately predict their SDL in an online learning setting, suggesting that the two constructs are indeed related to each other.
Nevertheless, specific quantitative studies investigating the possible effect of learners' SDL and resilience towards their achievements in English as L2 class in the Indonesian context are still very rare, if not non-existent. Besides, in contrast to the general trend on the predictive ability of resilience towards L2 achievement in many previous studies (e.g.: Khajavy et al., 2019; Kim \& Kim, 2016; Malekan \& Hajimohammadi, 2017; Najafzadeh et al., 2019), a study by Karabiyik (2020) in Turkey found that learners' perseverance, one characteristic of resilience, could not predict their academic achievement as measured with their GPA, probably suggesting that further studies investigating the relationship between resilience and L2 achievement are needed to obtain a more established inference. In addition, the findings on the relationships between learners' SDL and L2 achievement, as previously mentioned, have so far been inconsistent. For these reasons, it could be worthwhile to conduct a quantitative study investigating Indonesian learners' SDL and resilience in relation to their L2 achievement. With these mentioned rationales, the present study seeks to answer the following research questions: First, is there any effect of learners' SDL towards their L2 achievement?. Second, is there any 
effect of learners' resilience towards their L2 achievement?

\section{METHOD}

\section{Research design}

The present study used a survey as the method of data collection. This study was conducted in parallel with a previous study using the same set of questionnaires (Subekti, 2021). Subekti (2021) investigated the relationship between learners' SDL and their resilience. The present study, along with the study by Subekti (2021), adapted fifteen questionnaire items indicating SDL applicable to the L2 learning context from Ayyildiz's and Tarhan's (2015) Self-Directed Learning Skills Scale (SDLSS), which in total consists of 40 questionnaire items. Furthermore, the present study adapted twelve questionnaire items, designed by Wagnild and Young (1993) and termed Resilience Scale (RS). The original questionnaire consists of 25 items originally developed in the field of Nursing. Therefore, only twelve items applicable to the L2 learning context were used with necessary adjustments and modifications.

There were five possible responses: "Strongly agree" (5 points), "Agree" (4 points), "Neither agree nor disagree (3 points), "Disagree" (2 points) and "Strongly disagree" (1 point). There were two negative items in the SDL questionnaire in which "Strongly disagree" indicated high SDL. These items were reverse-scored. The Cronbach's alpha coefficient of the SDL questionnaire was at .78 indicating that the SDL questionnaire had quite high internal reliability. Furthermore, the Cronbach's alpha coefficient of the resilience questionnaire was at .86, indicating the questionnaire had a very high internal reliability.

The fifteen items on SDL adapted from Ayyildiz and Tarhan (2015) and the twelve items on resilience adapted from Wagnild and Young (1993) were translated into the Indonesian language and incorporated into one set of questionnaires which also included demographic information questions and whether the participants gave consent for their grades of EAP class to be used for the research purpose. The Indonesian version of questionnaires were piloted by three Indonesian nonEnglish department students. Two Indonesian English teachers also reviewed the questionnaire. This was to ensure that the questionnaire was accurate and simple to complete (Gray, 2014). Minor revisions were made per their feedback.

\section{Participants and ethical considerations}

The participants of the present study were 157 university learners 
studying at a private university in Java, Indonesia. Convenient sampling was employed in which the recruitment of participants was mostly based on the easiest access (Dornyei, 2007; Gray, 2014). The population was some 450 learners taking EAP classes. Of these 157 participants, $72(45.9 \%)$ were males and $85(54.1 \%)$ were females. The mean of the participants' age was 20.34, with the minimum being 18 and the maximum being $25(S D=1.35)$. These participants were taking EAP online classes in their respective departments in the first semester of the 2020/2021 academic year. The participants' departments could be observed in Table 1.

Table 1. The participants' departments

\begin{tabular}{llll}
\hline No & $\begin{array}{l}\text { Department } \\
\text { s }\end{array}$ & $\begin{array}{l}\text { Number } \\
\text { of } \\
\text { participan } \\
\text { ts }\end{array}$ & $\begin{array}{l}\text { Percentag } \\
\text { e }\end{array}$ \\
\hline 1 & Management & 52 & $33.1 \%$ \\
\hline 2 & Biology & 38 & $24.2 \%$ \\
\hline 3 & Architecture & 23 & $14.6 \%$ \\
\hline 4 & $\begin{array}{l}\text { Product } \\
\text { Design }\end{array}$ & 23 & $14.6 \%$ \\
\hline 5 & Accounting & 11 & $7 \%$ \\
\hline 6. & Informatics & 10 & $6.4 \%$ \\
\hline
\end{tabular}

As at the time of data collection these participants were studying online due to the Covid-19 pandemic, they resided in various islands or places in Indonesia. Table 2 presented the participants' islands of residence at the time of the data collection.
Table 2. The participants' islands of residence

\begin{tabular}{llll}
\hline No & Islands & $\begin{array}{l}\text { Number of } \\
\text { participant } \\
\text { s }\end{array}$ & $\begin{array}{l}\text { Percentag } \\
\text { e }\end{array}$ \\
\hline 1 & Java & 108 & $68.8 \%$ \\
\hline 2 & Kalimantan & 14 & $8.9 \%$ \\
\hline 3 & Sulawesi & 12 & $7.6 \%$ \\
\hline 4 & Sumatera & 8 & $5.1 \%$ \\
\hline 5 & Papua & 5 & $3.2 \%$ \\
\hline 6. & $\begin{array}{l}\text { Nusa } \\
\text { Tenggara }\end{array}$ & 5 & $3.2 \%$ \\
\hline 7 & Bali & 2 & $1.3 \%$ \\
\hline 8 & $\begin{array}{l}\text { Other } \\
\text { islands/plac } \\
\text { es }\end{array}$ & 3 & $1.9 \%$ \\
\hline & The 157 partipants & \\
\hline
\end{tabular}

The 157 participants of the present study were also the majority of the 187 participants of the present study's paralleled study (Subekti, 2021). 30 participants of the study by Subekti (2021) were excluded from the present study because they did not allow their grades in the EAP classes to be used, and as such their decision was respected. This was the implementation of a research ethics principle, voluntary participation (Israel \& Hay, 2006). The questionnaire distribution was conducted with the help of the EAP class teachers within the period of October up to November 2020 after permission to conduct research was obtained from the respective heads of departments as the gatekeepers of the target participants (Ramrathan, Grange, \& Shawa, 2016). The class teachers had the liberty as to when to distribute the questionnaires within this period considering the respective classes' 
agenda. It was to minimise disruption, and thus avoiding possible harm (Israel \& Hay, 2006).

Learners' grades were obtained through the help of the class teachers per whether learners gave consent for their grades to be used for this study's purpose. The grades were the participants' final grades obtained in their respective EAP classes in the first semester of the 2020/2021 academic year. Only learners who gave this consent were involved in the present study, thus the exclusion of 30 learner participants of the study by Subekti (2021) from the present study as previously mentioned.

\section{Data analysis}

The questionnaire was distributed in the form of Google Form, the responses of which were then recorded in SPSS 25. From the total 187 participants filling out the questionnaires, 30 participants did not give their consent for their grades to be used for research purposes. Hence, their data were only used for the study by Subekti (2021) and were excluded from the present study, involving learners' grades as the parameter of L2 achievement.

The data from the other 157 participants were then further analysed using Pearson's correlation and regression formulas to find the association between learners' SDL and L2 achievement as well as their resilience and L2 achievement. The sequence of data analysis could be observed in Figure 1.

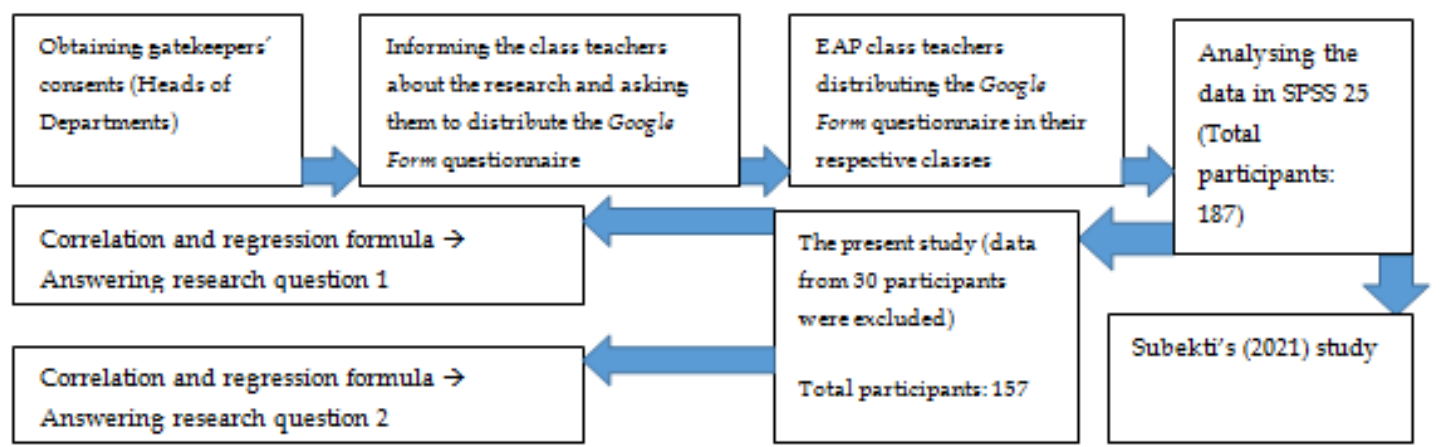

Figure 1. The sequence of data analysis 


\section{FINDINGS AND DISCUSSION}

\section{Findings}

The learner participants' mean of grades was 79.30 with the minimum being 3.67 and the maximum being $97.38(S D=17.14)$. The composite mean score of the fifteen SDL items was 59.37 $(S D=6.19)$ indicating the mean score of approximately 3.96 in each item, suggesting a high level of SDL. Furthermore, the composite mean score of the twelve items on resilience was $48.55(S D=6.14)$ indicating the mean score of approximately 4.05 in each item. This suggested that the learner participants had a high level of resilience in general.

\section{The predictive power of learners'} SDL towards their L2 achievement

Through a Pearson's correlation analysis, the present study found a very weak positive correlation between learners' SDL and their L2 achievement as seen in their grades, with the correlation being statistically nonsignificant, $r(155)=.01, p>.05$. The complete result could be observed in Table 3.

To see the extent to which learners' SDL could predict their grades, a regression formula was executed. The detailed result could be seen in Table 4 .
Table 3. Correlation between learners' SDL and their L2 achievement

\begin{tabular}{llll}
\hline & & $\begin{array}{l}\text { Learners' } \\
\text { Achievement }\end{array}$ & L2 \\
\hline \multirow{2}{*}{$\begin{array}{lll}\text { Learners' } \\
\text { SDL }\end{array}$} & $\begin{array}{l}\text { Pearson } \\
\text { Correlation }\end{array}$ & .011 \\
\cline { 2 - 3 } & Sig. (2-tailed) & .891 \\
\cline { 2 - 3 } & $\mathrm{N}$ & 157 \\
\hline
\end{tabular}

Table 4. Regression results with learners' SDL as the independent variable

\begin{tabular}{|c|c|c|c|}
\hline Model & $\mathbf{R}$ & R Square & $\begin{array}{l}\text { Adjusted } \\
\text { Square }\end{array}$ \\
\hline 1 & $.011^{\mathrm{a}}$ & .000 & -.006 \\
\hline
\end{tabular}

As seen in Table 4, the study found that the value of $R^{2}$ was .000 . It indicated that learners' SDL could not predict their grades. There were other variables, making up almost $100 \%$, not involved in this formula affecting their grades.

\section{The predictive power of learners' resilience towards their L2 achievement}

As seen in Table 5, the present study found a negative weak relationship between learners' resilience and their grades in English class. This indicated that the higher learners' resilience, the lower their achievement in English. However, the relationship was not significant, $r(155)=-.02, p>$ .05 . 
Table 5. Correlation between learners' resilience and their $\mathrm{L} 2$ achievement

\begin{tabular}{lll}
\hline & & $\begin{array}{l}\text { Learners' } \\
\text { achievement }\end{array}$ \\
\hline \multirow{2}{*}{$\begin{array}{lll}\text { Learners' } \\
\text { resilience }\end{array}$} & Pearson & -.021 \\
\cline { 2 - 3 } & Correlation & \\
\cline { 2 - 3 } & Sig. (2-tailed) & .793 \\
\hline
\end{tabular}

Furthermore, through a regression formula, the present study found that learners' resilience could not predict their grades in English class $\left(R^{2}=.000\right)$. The regression result could be observed in Table 6.

Table 6. Regression results with learners' resilience as the independent variable

\begin{tabular}{llll}
\hline Model & R & R Square & Adjusted R Square \\
\hline 1 & $.021^{\text {a }}$ & .000 & -.006 \\
\hline a. Predictors: (Constant), Learners' resilience
\end{tabular}

\section{Discussion}

The predictive power of learners' SDL towards their L2 achievement

The present study found the learner participants' SDL was weakly correlated with their L2 achievement and that their SDL could not predict their achievement. This finding was quite surprising considering that learners' SDL is often seen as a critical factor affecting the success of learning especially in the online setting (Zainuddin et al., 2019; Zhu et al., 2020). This finding was also in contrast with several findings of previous studies in the Iranian and Korean contexts indicating SDL as a predictive factor of
L2 achievement (e.g.: Cho \& Ma, 2015; Kim, 2014; Li \& Park, 2019; Majedi \& Pishkar, 2016). Regarding the contrasting findings, several possible factors could be in play. Three out of the four previous studies were conducted in Korea (Cho \& Ma, 2015; Kim, 2014; Li \& Park, 2019). This could suggest that it has been established that Korean learners' reported SDL level could predict their L2 achievement. That was to state that the Korean participants probably did what they reported in their SDL questionnaires. In comparison, the present study's Indonesian participants might not have done what they reported they had been doing. As for the present study's different findings from that of Majedi and Pishkar (2016), this difference could be attributed to the different methods between the two studies. Whilst the present study used a survey and used the participants' grades in their English classes, the study by Majedi and Pishkar (2016) was an experimental study with a speaking accuracy test as the measurement of L2 achievement where intensive self-directed learning method was purposely implemented.

Despite the present study's different finding from the previously mentioned findings of several studies, this present study's finding was in line with the findings of other previous studies suggesting no significant 
relationship between learners SDL and their achievement (e.g.: Hadi et al., 2014 in Iran; Xuan et al., 2018 in Malaysia). The same as the present study's participants, the participants participating in the study by Xuan et al. (2018) were also non-English department students. In this case, the rather similar characteristics between the participants of both studies could be at play affecting this same finding. Furthermore, regarding the same finding of the present study with that of Hadi et al. (2014) in Iran, the fact that both Indonesia and Iran considered English as a foreign language (EFL) whose usage was confined in classroom uses could also influence the degree of learners' SDL in learning English in both studies. This EFL setting could play a part in affecting learners' SDL in addition to the quality of online learning instruction (Sumuer, 2018; Zainuddin et al., 2019; Zhu et al., 2020).

\section{The predictive power of learners' resilience towards their L2 achievement}

The present study found that learners' resilience could not predict their L2 achievement. This finding was the same as the finding of a recent study by Karabiyik (2020) in Turkey reporting that learners' resilience could not predict their GPA. Regarding this, other factors which were possibly more dominant such as aptitude could be at play in both studies. This present study's finding, however, was in contrast with the general trend in resilience literature in which many previous studies have found that learners' resilience was a significant predictor of various L2 achievement in various learning contexts (e.g.: Abolmaali \& Mahmudi, 2013; Kamali \& Fahim, 2011; Khajavy et al., 2019; Kim \& Kim, 2016; Malekan \& Hajimohammadi, 2017; Najafzadeh et al., 2019). Considering the plethora of research suggesting the positive predictive power of resilience towards achievement, the present study's finding was very surprising and at least two factors could be accounted for this particular finding.

The first factor was that the resilience construct measured in the questionnaire was more on positive self-talk and this might not be directly related to their grades in English classes. Classroom-specific resilience attitudes might be more directly related to learners' grades rather than resilience in a more general sense. However, to point out this particular factor as the determinant was not quite convincing either. That was because thus far, many resilience studies in L2 learning contexts also employed questionnaires on general resilience attitudes. Hence, it could be stated that the present study's 
finding was quite unprecedented, suggesting further studies in the Indonesian context are needed for more conclusive findings.

The second factor that was possibly at play was the measurement of L2 achievement in the present study which might not be standardised. As the participants were from different EAP classes, each class very possibly had different tasks to complete, and so different scoring components and rubrics. Hence, though the scoring range was the same (from 0 to 100), the level of difficulty to achieve it may have been heterogeneous. In addition, as each class was taught by different teachers, each teacher might have had their grading standard, which could further affect the L2 achievement component in the present study.

\section{CONCLUSION AND SUGGESTIONS}

The present study investigated English as L2 learners' SDL and resilience and their predictive power towards their L2 achievement in the Indonesian context which was quite under-researched regarding this particular field. However, this study surprisingly found that neither learners' SDL nor their resilience could predict their achievement in English despite the plethora of research in many other learning contexts suggesting the power of these two constructs in influencing learners' L2 achievement. The present study's finding could be perplexing for both English teachers and researchers in the field. However, rather than drawing a too early conclusion on the SDL-achievement and resilienceachievement relationships, further studies in the same Indonesian context are necessary for a more solid conclusion. Regarding the present study's surprising findings, future researchers investigating the Indonesian context could employ instruments measuring more classroom-specific SDL and resilience attitudes rather than the general ones to optimise the possibility of participants reporting what they do or have been doing rather than what they should do. A more uniformed criterion of L2 achievement may also be employed, for instance, grades measuring learners' achievement in the same language tasks.

\section{Acknowledgement}

I would like to express my gratitude towards the Heads of Departments who granted permission to conduct this study in their EAP classes. My gratitude also goes to all EAP teachers who helped distribute the questionnaires and all participants without whom this study could not have been completed. 


\section{REFERENCES}

Abolmaali, K., \& Mahmudi, R. (2013). The prediction of academic achievement based on resilience and perception of the classroom environment. Open Science Journal of Education, 1(1), 7-12.

Atmojo, A. E. P., \& Nugroho, A. (2020). EFL classes must go online! Teaching activities and challenges during COVID-19 pandemic in Indonesia. Register Journal, 13(1), 49-76.

Ayyildiz, Y., \& Tarhan, L. (2015). Development of the self-directed learning skills scale. International Journal of Lifelong Education, 34(6), 1-17.

https://doi.org/10.1080/0260137 0.2015 .1091393

Basereh, N., \& Pishkar, K. (2016). Selfdirected learning and self-efficacy belief among Iranian EFL learners at the advanced level of language proficiency. Journal of Applied Linguistics and Language Research, 3(1), 232-240.

Cho, Y. A., \& Ma, J. H. (2015). The relationships between the selfdirected learning, language strategies, and English proficiency in L2 learning. The Linguistic Association of Korea Journal, 23(3), 49-67.

Danesh, J., \& Shahnaazari, M. (2020). A structural relationship model for resilience, L2 learning motivation, and L2 proficiency at different proficiency levels. Learning and Motivation, 72. https://doi.org/10.1016/j.lmot.20 20.101636

Dornyei, Z. (2007). Research methods in applied linguistics (First edit). Oxford: Oxford University Press.

$\mathrm{Fu}$, J. S. (2013). ICT in education: A critical literature review and its implications. International Journal of Education and Development Using Information and Communication Technology (IJEDICT), 9(1), 112125.

Gray, D. E. (2014). Doing research in the real world (3rd ed.). London: Sage Publications, Ltd.

Gunawan, G., Suranti, N. M. Y., \& Fathoroni, F. (2020). Variations of models and learning platforms for prospective teachers during the COVID-19 pandemic period. Indonesian Journal of Teacher Education, 1(2), 61-70.

Hadi, M. M., Kalantari, B., \& Ghaslani, R. (2014). Self-Regulated Learning (SRL), motivation, and language achievement of Iranian EFL Learners. Procedia - Social and Behavioral Sciences, 98, 1062-1068.

Hagger, M. S., \& Hamilton, K. (2018). Grit and self-discipline as predictors of effort and academic attainment. British Journal of Educational Psychology. https://doi.org/10.1111/bjep.122 41 
Israel, M., \& Hay, I. (2006). Research ethics for social scientists. London: Sage Publications.

Kamali, Z., \& Fahim, M. (2011). The relationship between critical thinking ability of Iranian EFL learners and their resilience level facing unfamiliar vocabulary items in reading. Journal of Language Teaching and Research, 2(1), 104-111.

Karabiyik, C. (2020). Interaction between academic resilience and academic achievement of teacher trainees. International Online Journal of Education and Teaching, 7(4), 1585-1601.

Khajavy, G. H., Makiabadi, H., \& Navokhi, S. A. (2019). The role of psychological capital in language learners' Willingness to Communicate, motivation, and achievement. Eurasian Journal of Applied Linguistics, 5(3), 495-513. https://doi.org/10.32601/ejal.651 346

Kim, T. Y. (2014). The relationships between Self-directed Learning Readiness, learning strategies, and achievement: A case of Korean High School English learners. Konkuk University Graduate School of Education.

Kim, T. Y., \& Kim, Y. (2020). Structural relationship between L2 learning motivation and resilience and their impact on motivated behavior and L2 proficiency. Journal of Psycholinguistic Research. https://doi.org/10.1007/s10936020-09721-8.

Kim, T. Y., \& Kim, Y. K. (2016). The impact of resilience on L2 learners' motivated behaviour and proficiency in L2 learning. Educational Studies, 1-15. https://doi.org/10.1080/0305569 8.2016.1237866.

Kim, T. Y., Kim, Y., \& Kim, J. Y. (2018). Role of resilience in (de)motivation and second language proficiency: Cases of Korean elementary school students. Journal of Psycholinguistic Research, 48(2), 371-389.

https://doi.org/10.1007/ s10936018-9609-0.

Ko, H. S. (2018). Self-directed learning and English proficiency by Korean Learners. English Teaching, 73(1), 49-69. https://doi.org/10.15858/engtea. 73.1.201803.49

Lancker, W. V., \& Parolin, Z. (2020). Comment COVID-19, school closures, and child poverty: A social crisis in the making. The Lancet Public Health, 2019(20), 2019-2020.

https://doi.org/10.1016/S24682667(20)30084-0.

Li, N., \& Park, H. (2019). The relationships of Self-directed Learning Readiness and motivation with the English proficiency of Korean EFL 
learners. Studies in English Language \& Literature, 45, 153-181.

Majedi, N., \& Pishkar, K. (2016). The effect of Self-directed Learning on Iranian intermediate EFL learners' speaking accuracy. Journal of Applied Linguistics and Language Research, 3(2), 86-95.

Malekan, F., \& Hajimohammadi, R. (2017). The relationship between Iranian ESP Learners' translation ability and resilience in reading comprehension. International Journal of Education and Literacy Studies, 5(2), 47-52. https://doi.org/10.7575/aiac.ijels .v.5n.2p.47.

Najafzadeh, M., Jahedizadeh, S., \& Ghanizadeh, A. (2019). A dynamic model of EFL learners' personal best goals, resilience, and language achievement. International and Multidisciplinary Journal of Social Sciences, 2(2018), 267-296.

https://doi.org/10.17583/rimcis. 2018.3011.

Nguyen, K., Stanley, N., Stanley, L., \& Wang, Y. (2015). Resilience in language learners and the relationship to storytelling. Cogent Education, 2(1), 1-16.

Onyema, E. M., Eucheria, N. C., Obafemi, F. A., Sen, S., Atonye, F. G., Sharma, A., \& Alsayed, A. O. (2020). Impact of coronavirus pandemic on education. Journal of Education and Practice, 11(13), 108121.
https://doi.org/10.7176/JEP/1113-12.

Park, K. Y., Sung, T. S., \& Joo, C. W. (2018). On the relationship between college students' attitude toward the Internet and their selfdirected English learning ability. Journal of Korea Society of Computer and Information, 23(2), 117-123.

Plaisance, M. (2018). Online course delivery. In J. I. Liontas (Ed.), The TESOL encyclopedia of English language teaching (First Edit). https://doi.org/https://doi.org/ 10.1002/9781118784235.eelt0129.

Ramrathan, L., Grange, L., \& Shawa, L. B. (2016). Ethics in educational research. In Education studies for initial teacher development (pp. 432443).

Rapanta, C., Botturi, L., Goodyear, P., \& Guàrdia, L. (2020). Online university teaching during and after the Covid-19 crisis: Refocusing teacher presence and learning activity. Postdigital Science and Education, 2, 923-945.

Rashid, T., \& Asghar, H. M. (2016). Technology use, self-directed learning, student engagement and academic performance: Examining the interrelations. Computers in Human Behavior, 63, 604-612.

https://doi.org/10.1016/j.chb.201 6.05.084.

Simons, J., Beaumont, K., \& Holland, L. (2018). What factors promote student resilience on a level 1 
distance learning module? The Journal of Open, Distance and eLearning, 33(1), 4-14. https://doi.org/10.1080/0268051 3.2017.1415140.

Subekti, A. S. (2020). Covid-19triggered online learning implementation: Pre-service English teachers' beliefs. Metathesis: Journal of English Language Literature and Teaching, 4(3), 232-248.

Subekti, A. S. (2021). Indonesian L2 learners' resilience and selfdirected learning in online classes: A correlational study. JEELS (Journal of English Education and Linguistics Studies), 8(1), 27-47.

Sumuer, E. (2018). Factors related to college students' self-directed learning with technology. Australasian Journal of Educational Technology, 34(4), 29-43.

Sze-yeng, F., \& Hussain, R. M. R. (2010). Self-directed learning in a socioconstructivist learning environment. Procedia - Social and Behavioral Sciences, 9, 1913-1917. https://doi.org/https://doi.org/ 10.1016/j.sbspro.2010.12.423.

Uz, R., \& Uzun, A. (2018). The influence of blended learning environment on self-regulated and self-directed learning skills of learners. European Journal of Educational Research, 7(4), 877-886. https://doi.org/10.12973/eujer.7.4.877.
Wagnild, G., \& Young, H. (1993). Development and pshycometric evaluation of a resilience scale. Journal of Nursing Measurement, 1(2), $\quad$ 165-178. https://doi.org/10.1016/j.apnu.2 010.05.001.

Xuan, L. Y., Razali, A. B., \& Samad, A. A. (2018). Self-directed Learning Readiness (SDLR) among foundation students from high to low proficiency levels to learn English language. Malaysian Journal of Learning and Instruction, 15(2), 55-81.

Zainuddin, Z., Habiburrahim, H., Muluk, S., \& Keumala, C. M. (2019). How do students become self-directed learners in the EFL flipped-class pedagogy? A study in higher education. Indonesian Journal of Applied Linguistics, 8(3), 678-690.

https://doi.org/10.17509/ijal.v8i 3.15270 .

Zhu, M., Bonk, C. J., \& Doo, M. Y. (2020). Self-directed learning in MOOCs: Exploring the relationships among motivation, self-monitoring, and self-management. Educational Technology Research and Development. https://doi.org/10.1007/s11423020-09747-8. 